\title{
Post-fire survival and regeneration of Eucalyptus globulus in forest plantations in Portugal
}

\author{
Filipe X. Catry ${ }^{a, *}$, Francisco Moreira ${ }^{a}$, Rui Tujeira ${ }^{a}$, Joaquim S. Silva ${ }^{a, b}$ \\ a Technical University of Lisbon, Institute of Agronomy, Centre for Applied Ecology, Tapada da Ajuda, 1349-017 Lisboa, Portugal \\ ${ }^{\mathrm{b}}$ Polytechnic Institute of Coimbra, School of Agriculture, 3040-316 Coimbra, Portugal
}

\section{A R T I C L E I N F O}

\section{Article history:}

Received 19 June 2013

Received in revised form 15 August 2013

Accepted 17 August 2013

Available online 11 September 2013

\section{Keywords:}

Wildfire

Modelling

Mortality

Top-kill

Resprouting

Eucalyptus globulus

\begin{abstract}
A B S T R A C T
Eucalyptus globulus is one of the most important pulpwood plantation species in the world, and nowadays it is present in most continents. Some of the regions where E. globulus plantations have been expanding have a high incidence of wildfires; therefore, knowing the factors affecting the fire resistance and resilience of this species is particularly important for forest management. This is the case of Portugal, where nearly 1.4 million ha of land burned in the last decade and where E. globulus has become the most widespread tree species. In this paper we assessed the short-term post-fire responses of E. globulus trees in four sites affected by wildfires, and investigated their potential relationships with fire severity descriptors and with tree and stand characteristics. One year after fire, individual tree mortality was low (3.9\%) but most trees (79.2\%) were top-killed (i.e. had stem mortality). Both post-fire tree mortality and top-kill increased with fire severity (expressed by maximum char height and/or char severity rating). Moreover, top-kill was positively related with vegetation cover and the proportion of pine trees in the stand, and was negatively related with tree diameter and the proportion of other broadleaved trees in the stand. The most common post-fire regeneration type among the sampled trees was basal resprouting (89.2\%), though $20.9 \%$ had epicormic resprouting. The number of basal resprouts increased with char height, top-kill and diameter of the parent tree, and decreased with slope. In terms of post-fire growth, the height of the dominant resprout increased with the number of resprouts and with char severity, while it decreased in drier southern aspects. Results showed that E. globulus is a fire-resilient species with a very high probability of surviving fire; however, in forest plantations where trees are usually felled in short rotations (thus with limited size), individuals have a high probability of being top-killed. The presented models may be useful to help managers on the assessment of post-fire production losses and regeneration potential in E. globulus plantations.
\end{abstract}

(c) 2013 Elsevier B.V. All rights reserved.

\section{Introduction}

Eucalypts are native to Australasia but some species have been widely planted in many countries, mainly because of their fast growth, wood characteristics and ability to withstand dry and low nutrient conditions (Florence, 1996). One of these species, Eucalyptus globulus Labill. (Tasmanian blue gum), is nowadays one of the most important pulpwood plantation species in the world, having great economic importance (Potts, 2004). This eucalypt is native to south-eastern Australia (Tasmania and southern Victoria; Dutkowski and Potts, 1999) and was introduced in all continents except Antarctica (in Europe introduction occurred more than 150 years ago; Goes, 1977). In 2004 there were estimated to be over 2.5 million hectares of E. globulus planted

\footnotetext{
* Corresponding author. Tel.: +351 213653333; fax: +351 213653290.

E-mail addresses: fcatry@isa.utl.pt (F.X. Catry), fmoreira@isa.utl.pt (F. Moreira), geral@ruitujeira.com (R. Tujeira), jss@esac.pt (J.S. Silva).
}

worldwide, with the main concentration of plantations occurring in the Iberian Peninsula (Potts et al., 2004). According to the Portuguese Forest Inventory, E. globulus is now the most widespread tree species representing $26 \%$ ( $812000 \mathrm{ha}$ ) of the total forest cover (ICNF, 2013). In Portugal this species is cultivated through a coppice system (10-12 year rotations) and the wood is almost exclusively sold to pulp mills which in turn supply papermaking industries in different parts of the world; however, rotation cycle and main uses varies among countries (e.g. Pohjonen and Pukkala, 1990).

Some of the regions where E. globulus has been expanding also present a high incidence of wildfires. This is the case of Portugal and Spain in the Iberian Peninsula; in Portugal alone nearly 1.4 million ha of land burned in the last decade (JRC, 2012). Moreover, the perspectives under a climate change scenario indicate a very significant increase of the annual burned area in these and other countries (Flannigan et al., 2009; Amatulli et al., 2013). Planted stands dominated by E. globulus are known for being highly 
fire-prone in comparison to other forest systems (Nunes et al., 2005; Moreira et al., 2009b; Silva et al., 2009; Fernandes et al., 2011; Xanthopoulos et al., 2012). Therefore the impact of wildfires on E. globulus plantations is an important issue to address, both from economic and ecologic perspectives.

Most eucalypt species in their native range are subject to fires and many have characteristics indicative of adaptation to a particular regime of fire intensity, frequency and season (Florence, 1996; Gill, 1997). However, mortality and regeneration type of eucalypt species are known to be quite variable (Gill, 1997). Although various studies assessed the post-fire responses of several eucalypt species (e.g. Strasser et al., 1996; Vivian et al., 2008; Waters et al., 2010), there are still many (including E. globulus) for which post-fire responses remain poorly known; furthermore, very few studies investigated eucalypt responses in forest plantations beyond their native range.

Whether trees survive or die after fire and the type and extent of recovery, will depend on the type and extent of damage (e.g. Gill, 1997). Post fire tree responses may vary with fire behaviour characteristics as these are directly related with the level of tree damage. Fire behaviour variables like fire intensity or flame height are a direct consequence of surface and crown fuels (Van Wagner, 1977; Rothermel, 1983); therefore the assessment of fuel-related variables like shrub cover and tree cover can be of interest for the establishment of relationships with tree responses (e.g. Moreira et al., 2007). Additionally, topographic conditions, such as slope and aspect, have a direct influence on fire behaviour (Rothermel, 1983), but also on the vegetative conditions of each tree and surrounding vegetation, particularly in Mediterranean-type ecosystems (Kutiel and Lavee, 1999; Sternberg and Shoshany, 2001; Catry et al. 2009). Post-fire tree responses may also vary with species (which possess different regeneration and fire-resistance traits), individual tree characteristics important for fire resistance or avoidance (e.g. size, bark thickness), tree physiological condition when the fire occurs (e.g. availability of energy reserves to fund regrowth), and management factors (Whelan, 1995; DeBano et al., 1998; Catry et al., 2013).

Although several eucalypt species are sensitive to fire and are killed after full crown scorch (depending on seed for regeneration; classified as obligate seeders), the vast majority are fire-resistant and will recover from damages by vegetative regeneration (classified as resprouters) (Florence, 1996; Strasser et al., 1996; Gill, 1997; Burrows, 2013; Clarke et al., 2013). Indeed, less than $10 \%$ of the more than 900 eucalypt taxa have been classified as obligate seeders (Nicolle, 2006). The principal mechanisms of recovery in fire-resistant eucalypt species are resprouting from epicormic strands (i.e. regeneration from meristem strips, usually extending from the inner to outer bark on aboveground branches and stems, which produce buds), and/or from basal buds (i.e. regeneration from a lignotuber or the root collar, at or just below soil level) (Gill, 1997; Waters et al., 2010; Burrows, 2002, 2013).

E. globulus is known by strong resprouting capacity after disturbance, which may be explained by high epicormic bud initiation potential and the presence of a lignotuber (Burrows, 2002; Whittock et al., 2003). Although some mortality may occur in burned plantations, many trees are likely to survive by resprouting. In one of the few studies on post-fire survival of E. globulus, Catry et al. (2010) found $100 \%$ survival in a sample of 60 burned trees, monitored over 4 years. In another study, Marques et al. (2011) reported $47 \%$ of dead trees, but these results most likely refer to stem mortality instead of individual mortality. This is the only study to our knowledge that attempted to relate mortality with other factors, although no fire characteristics were used. However, we could not find any references for $E$. globulus, relating the different types of post-fire tree response with stand and tree characteristics, nor with fire severity descriptors.
In this paper we analyse data collected in several sites that burned in the same fire season. We aimed to: (1) characterise the post-fire responses of E. globulus in terms of individual tree survival and resprouting behaviour; (2) investigate through modelling which are the main fire, tree and stand characteristics influencing these responses at the tree-level. Both fire, tree and stand characteristics can be partly managed, which enables some control on mortality and regeneration of burned trees. Therefore, the identification of these factors and forecasting of tree responses may allow minimizing fire damage through adequate planning and management of E. globulus plantations.

\section{Methods}

\subsection{Study sites}

We used data from four different locations in central Portugal, western Mediterranean Basin (Fig. 1). Each of these locations was affected by a wildfire in the summer of 2006 (July through September; Table 1), which corresponds to the normal fire season (dry season). The climate in the four study sites is Mediterranean, with mean annual temperatures ranging from 15 to $17.5^{\circ} \mathrm{C}$ and precipitation ranging from 700 to $1400 \mathrm{~mm}$ (IA, 2003; Table 1). Elevation ranges from 120 to $580 \mathrm{~m}$.

\subsection{Sampling and data collection}

In the four wildfire sites we used a regular grid $(300 \mathrm{~m})$ of points covering the burned area and defined a circular plot $(50 \mathrm{~m}$ radius, $7850 \mathrm{~m}^{2}$ ) around each point. We overlaid these plots with land cover maps (scale 1:25000) and selected those located in eucalypt areas and where no post-fire interventions occurred. In total, 22 plots were sampled (Table 1). In plots with 20 E. globulus trees or less, all individuals inside the plot were assessed; otherwise, we laid out up to four $50-\mathrm{m}$ strip transects ( $20 \mathrm{~m}$ wide) and sampled trees (starting from north and proceeding clockwise) until obtaining 20 individuals per plot. Only trees with at least $5 \mathrm{~cm}$ diameter at breast height were sampled, and overall we sampled 388 E. globulus individuals. Data collection was performed $12-14$ months after fire occurrence (12 months in all sites but Atouguia).

We recorded several tree characteristics, fire severity indicators and environmental variables (Table 2). We assessed whether each tree was dead or alive (trees were considered dead when no green foliage was present regardless of its location), and the regeneration type if alive, that is, if trees were resprouting from belowground organs (root collar or lignotuber, hereafter named basal resprouting) and/or from aboveground organs (crown or stem, hereafter named epicormic resprouting). As a result, the post-fire regeneration status of each tree (RS) was recorded as dead (no regeneration), basal resprouting only, simultaneous basal and epicormic resprouting, or epicormic resprouting only, following a decreasing gradient of fire-inflicted damage (Moreira et al., 2009a). Additionally, we classified the number of basal resprouts per tree into 5 frequency categories $(0,1-5,6-10,11-20,>20)$, and measured the height of the dominant (tallest) resprout (HDR, measured with a laser hypsometer to the nearest $0.1 \mathrm{~m}$ ).

Tree size measurements included total tree height $(H$, measured with a laser hypsometer to the nearest $0.1 \mathrm{~m}$ ) and diameter at breast height ( $\mathrm{DBH}$, measured at $1.30 \mathrm{~m}$ above ground level to the nearest $1 \mathrm{~cm}$ ). Bark thickness (BT) was not measured on burned trees because the bark is often partially consumed by fire and may detach from the stem; alternatively, we measured BT and DBH on 60 nearby unburned trees (DBH range $=5.2-50.3 \mathrm{~cm}$ ) and estimated BT for each burned tree from the derived allometric 


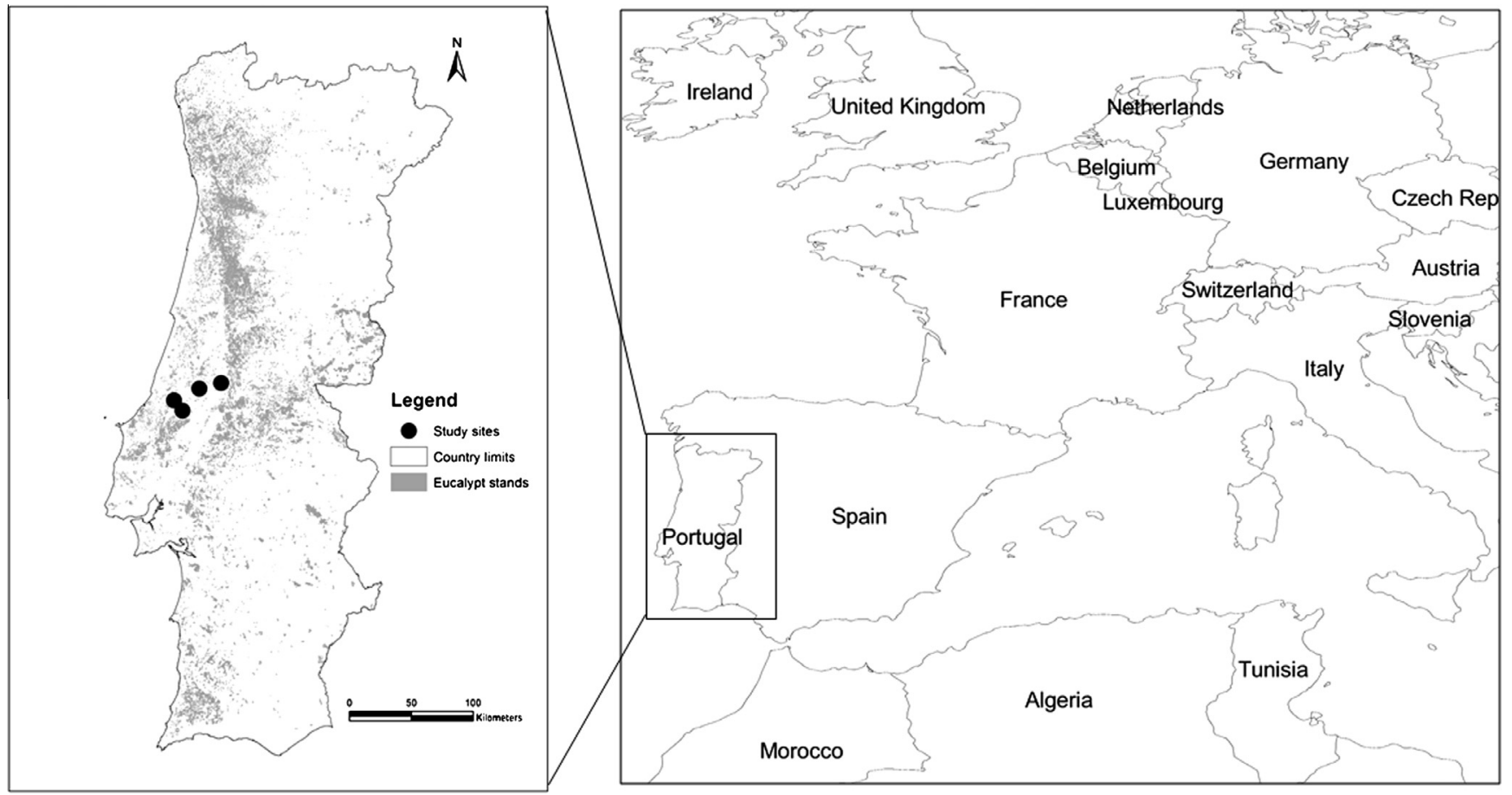

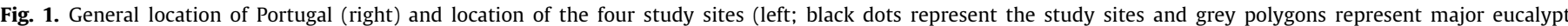
plantations).

Table 1

List of the four study sites.

\begin{tabular}{lllll}
\hline Site name & $n$ Trees & $n$ Plots & Fire date & Burned area (ha) \\
\hline Agroal & 90 & 5 & September 2006 & 375 \\
Atouguia & 92 & 5 & July 2006 & 261 \\
P. Mós & 123 & 8 & August 2006 & 2964 \\
V. Florido & 83 & 4 & August 2006 & 252 \\
\hline
\end{tabular}

$n$ Trees, number of sampled trees; $n$ plots, number of established plots.

equation $\left(\mathrm{BT}=0.093 * \mathrm{DBH}^{0.732} ; R^{2}=0.854\right)$. Bark thickness measurements (to the nearest $0.1 \mathrm{~cm}$ ) were performed at $1.30 \mathrm{~m}$ with a bark gauge, and represent the average of two measurements at opposite sides of the trunk.

We also assessed two commonly used indicators of fire severity and potential tree injury (Woolley et al., 2012; Thies and Westlind, 2012): the proportion of maximum tree height charred (PCH) and bole char severity (CS). First, the maximum bole char height (the vertical extent of blackening of the outer bark) was measured in each tree $(\mathrm{CH}$, measured with a laser hypsometer to the nearest $0.1 \mathrm{~m}$ ); then, we calculated the proportion of maximum bole char height $(\mathrm{PCH})$ as $\mathrm{CH}$ relative to total tree height. Second, bole char severity (CS) was assessed and classified in four categories

Table 2

Summary of the variables assessed in four wildfires and used for modelling.

\begin{tabular}{|c|c|c|c|c|c|}
\hline Variable (code) & Units & Type $^{h}$ & Level & Mean (SD) & Range \\
\hline Tree regeneration status (RS) & 4 cat. $^{\mathrm{a}}$ & $\mathrm{R}, \mathrm{E}$ & Tree & - & - \\
\hline Number of basal resprouts (NBR) & 5 cat. $^{\text {b }}$ & $\mathrm{R}, \mathrm{E}$ & Tree & $2.15(1.3)$ & $0-4$ \\
\hline Height of the dominant basal resprout (HDR) & $\mathrm{m}$ & $\mathrm{R}$ & Tree & $3.3(1.1)$ & $0.5-7.1$ \\
\hline Diameter at breast height $(\mathrm{DBH})$ & $\mathrm{cm}$ & $\mathrm{E}$ & Tree & $10.0(6.5)$ & $5-60$ \\
\hline Tree height $(\mathrm{H})$ & $\mathrm{m}$ & $\mathrm{E}$ & Tree & $13.6(5.2)$ & $6-31$ \\
\hline Bark thickness (BT) & $\mathrm{cm}$ & $\mathrm{E}$ & Tree & $0.5(0.2)$ & $0.3-1.9$ \\
\hline Percentage of char height $(\mathrm{PCH})$ & $\%$ & $\mathrm{E}$ & Tree & $54.1(37.8)$ & $1-100$ \\
\hline Char severity rating (CS) & 3 cat. $^{c}$ & $\mathrm{E}$ & Tree & $2.0(0.4)$ & $1-3$ \\
\hline First rotation (FR) & 2 cat. $^{d}$ & $\mathrm{E}$ & Tree & $0.47(0.5)$ & $0-1$ \\
\hline Tree cover $(\mathrm{TC})$ & 3 cat. $^{\mathrm{e}}$ & $\mathrm{E}$ & Transect & $52.8(15.8)$ & $12.5-87.5$ \\
\hline Shrub cover (SC) & 5 cat. $^{\mathrm{f}}$ & $\mathrm{E}$ & Transect & $28.1(24.4)$ & $2.5-87.5$ \\
\hline Location in southern aspects (SA) & 2 cat. $^{g}$ & $\mathrm{E}$ & Transect & $0.4(0.5)$ & $0-1$ \\
\hline Slope (SL) & $\%$ & $\mathrm{E}$ & Transect & $15.4(9.7)$ & $0.0-30.6$ \\
\hline Percentage of pine trees (PP) & $\%$ & $\mathrm{E}$ & Plot & 14 & $0-95$ \\
\hline Percentage of other tree species (PO) & $\%$ & $\mathrm{E}$ & Plot & 10 & $0-97$ \\
\hline
\end{tabular}

a Tree regeneration status (R), 4 categories: dead, basal resprouting only, simultaneous basal and epicormic resprouting, or epicormic resprouting only.

b Number of basal resprouts (NR), 4 ordered categories: 0 (0 resprouts), 1 (1-5), 2 (6-10), 3 (11-20), $4(>20)$.

c Char severity rating (CS), 3 ordered categories: 1 (light), 2 (medium), or 3 (heavy).

d First rotation (FR), 2 categories: 1 (yes), or 0 (no).

e Tree cover (TC), 3 ordered categories: $<25 \%, 25-75 \%$, or $>75 \%$.

f Shrub cover (SC), 5 ordered categories: $<5 \%, 5-25 \%, 25-50 \%, 50-75 \%$, or $>75 \%$.

$g$ Location in southern aspects (SA), 2 categories: 1 (yes), or 0 (no).

$\mathrm{h}$ Type: variable used in the models as response (R) and/or explanatory (E). 
following criteria established by Ryan (1982). Definitions of these classes were: none: no evidence of flame contact with the bole and no charring; light: bark partially charred; medium: bark uniformly black, but bark character is still discernible; heavy: bark deeply charred, but not necessarily to the wood, with loss of bark superficial characteristics. Because cambial damage is usually greater near ground level than at breast height, bole char severity was based on the depth of bole char in the first $50 \mathrm{~cm}$ above ground (McHugh and Kolb, 2003).

In addition we recorded whether each individual tree was in the first rotation or not (FR; i.e. originating directly from seed and never harvested before, or from resprout origin). Typically, trees in the first rotation have a single stem and their age is lower than 12 years, while the others are multi-stemmed and older. In the case of multi-stemmed individuals, tree characteristics (namely size and bark thickness) and char severity refer to the largest stem. Tree post-fire responses refer to a given individual, regardless the number of stems it possesses (e.g. a tree is considered to be dead only if all stems are dead).

Since not all the plots were pure eucalypt stands, we counted the number of trees of each species and calculated at the plot-level: (i) the proportion of pine trees (PP; Pinus pinaster); and (ii) the proportion of other non-eucalypt broadleaved trees (PO). Total tree cover (TC) and shrub cover (SC) prior to fire were visually estimated at the transect-level during field assessments (based on the amount and size of burned tree and shrub remains and on resprouting vegetation) and with the help of aerial photographs taken before the fire. Tree cover was estimated using three categories $(<25 \%, 25-75 \%,>75 \%)$ and shrub cover according to five categories $(<5 \%, 5-25,25-50 \%, 50-75 \%,>75 \%)$. We also assessed the topographic conditions in each transect, namely the dominant slope (SL, measured with a hypsometer to the nearest $1 \%$ ) and aspect (8 categories); aspect was later simplified as a binary variable named southern aspects (SA; i.e., taking the value 1 for southern exposures S, SE or SW, which are drier conditions in the study area, and 0 for the remaining). The values for the plot and transect variables (Table 2) were used to characterise all trees in a given plot or transect.

\subsection{Data analysis}

The main data analysis was performed using generalized linear mixed-effects models (GLMM) (Bates et al., 2009; Zuur et al., 2009). As dependent variables we used the following post-fire tree responses: (i) individual mortality, i.e., mortality of all aboveground and belowground organs (tree death), (ii) top-kill (TK), i.e., death of all the aboveground biomass (thus including both live trees with basal resprouting only and dead trees), (iii) basal resprouting only, (iv) epicormic resprouting only, ( $v$ ) number of basal resprouts (NBR), and (vi) height of the dominant basal resprout (HDR). Variables (i) to (iv) were treated as binary (i.e., yes/no), and variables (v) and (vi) were treated as continuous. These post-fire responses were examined in relation to the different independent (explanatory) variables collected at the tree-, transect- and plot-level (Table 2). For modelling purposes the categorical variables FR and SA were treated as binary (i.e., yes/no), while the ordinal variables (TC, SC and CS) were treated as continuous: TC and SC were coded according to the midpoint of the respective categories; CS was coded as 1 (light), 2 (medium) and 3 (heavy), as there were no trees with the "none" category.

All the mixed models were fitted in $\mathrm{R}$ ( $\mathrm{R}$ Development Core Team, 2010) using the function glmer of the lme 4 package (binomial and gaussian families for binary and continuous responses, respectively; Bates et al., 2009), with wildfire site as a random effect. For each response variable assessed we started with a model including all explanatory variables and we used backward elimination to select the most important ones (Zuur et al., 2009). Model selection was performed by removing in each step the variable that explained less deviance, until all remaining variables in the model were significant $(p<0.05)$. Correlation between pairs of variables was checked using the Pearson correlation coefficient (between continuous variables) and the point biserial correlation (between continuous and dichotomous variables); when presenting a magnitude greater than \pm 0.6 , only one variable was used in the model in order to avoid collinearity (Zuur et al., 2009).

The Nagelkerke pseudo- $R^{2}$ (Nagelkerke, 1991) was used as an indicator of the proportion of variance explained by the models. Additionally, in the mortality and top-kill models (binary response variables), model performance was assessed by calculating the area under the receiver operating characteristics (ROC) curve (Hosmer and Lemeshow, 2000; Pearce and Ferrier, 2000). The ROC method has advantages in assessing model performance in a threshold-independent fashion, being independent of prevalence (Manel et al., 2001). Usually area under curve (AUC) values of 0.7-0.9 indicate useful applications and values above 0.9 indicate high accuracy (Swets, 1988).

\section{Results}

\subsection{Mortality and top-kill}

Our sampling captured a range of individual tree characteristics, as well as varying levels of fire severity (Table 2). Overall, $96.1 \%$ of the trees assessed regenerated vegetatively and were alive 1 year after the fire. Despite the low (3.9\%) post-fire mortality, most (79.2\%) sampled trees were top-killed (i.e., had stem death), while the remaining resprouted from epicormic (aerial) buds (Fig. 2).

Model results show that post-fire tree mortality increased with char severity (CS); however, model performance was relatively poor $\left(\mathrm{ROC}=0.77, R^{2}=0.08\right.$; Table 3 ). In contrast, the best model for predicting tree top-kill performed very well (Table 4). The proportion of maximum char height $(\mathrm{PCH})$, char severity $(\mathrm{CS})$, tree cover (TC), shrub cover (SC) and the proportion of pine trees (PP), all increased the probability of eucalypt top-kill, while tree diameter $(\mathrm{DBH})$ and the proportion of other broadleaved tree species (PO) had a negative effect on top-kill. The ROC curve indicated 95\% concordance between predicted probabilities and observed outcomes; the explained variance of this model was $59 \%$ (Table 4 ).

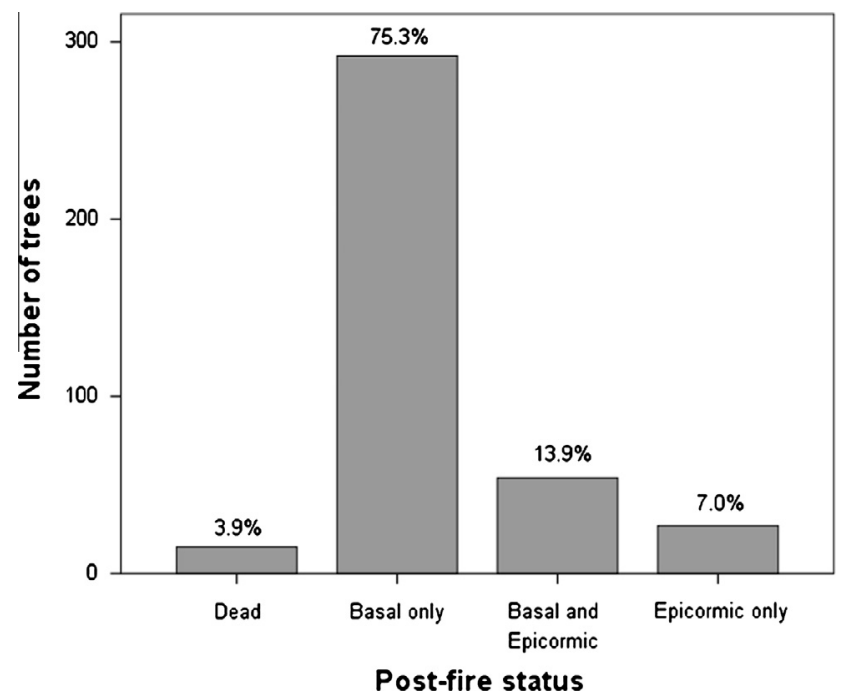

Fig. 2. Post-fire regeneration status of 388 E. globulus trees sampled in four wildfire sites. 
Table 3

Generalized linear mixed model to predict the probability of E. globulus mortality (M) 1 year after fire.

\begin{tabular}{llll}
\hline & Coefficients & $\chi^{2}$ & $P$-value \\
\hline$\beta_{0}$ & $-7.068 \pm 1.378$ & - & - \\
CS & $1.779 \pm 0.583$ & 9.120 & 0.003
\end{tabular}

Model coefficients ( \pm standard error): $\beta_{0}$, intercept; CS, char severity rating (cat.). Result of the likelihood ratio test $\left(\chi^{2}\right.$ and respective $P$-value). Model fit: area under ROC curve $=0.77$; Nagelkerke $R^{2}=0.08$.

Table 4

Generalized linear mixed models to predict the probability of $E$. globulus top-kill (TK) 1 year after fire. Both the selected model (above) and an alternative (simpler) model (below) are presented.

\begin{tabular}{llll}
\hline & Coefficients & $\chi^{2}$ & $P$-value \\
\hline Selected model & & & \\
$\beta_{0}$ & $-3.827 \pm 1.374$ & - & - \\
DBH & $-0.315 \pm 0.048$ & 88.942 & $<0.001$ \\
TC & $0.109 \pm 0.024$ & 22.803 & $<0.001$ \\
PP & $0.088 \pm 0.637$ & 21.333 & $<0.001$ \\
PO & $-0.055 \pm 0.015$ & 14.885 & $<0.001$ \\
PCH & $0.024 \pm 0.007$ & 13.159 & $<0.001$ \\
SC & $0.020 \pm 0.009$ & 5.116 & 0.024 \\
CS & $0.834 \pm 0.392$ & 4.155 & 0.042 \\
Alternative model & & & \\
$\beta_{0}$ & $2.838 \pm 0.731$ & - & - \\
DBH & $-0.224 \pm 0.035$ & 64.281 & $<0.001$ \\
PCH & $0.033 \pm 0.007$ & 35.046 & $<0.001$ \\
\hline
\end{tabular}

Model coefficients ( \pm standard error): $\beta_{0}$, intercept; DBH, diameter at breast height $(\mathrm{cm})$; TC, tree cover (\%); PP, percentage of pine trees in the plot (\%); PO, percentage of other species in the plot (\%); $\mathrm{PCH}$, maximum char height expressed as percentage of tree height (\%); SC, shrub cover (\%); CS, char severity rating (cat.). Results of the likelihood ratio test ( $\chi^{2}$ and respective $P$-value) to evaluate the importance of each variable (variables are ordered by decreasing order of importance). Model fit: Selected model: area under ROC curve $=0.95$; Nagelkerke $R^{2}=0.59$; Alternative model: $\mathrm{ROC}=0.93 ; R^{2}=0.50$.

A simpler model with just two variables (DBH and $\mathrm{PCH}$ ), still showed very good accuracy $\left(\mathrm{ROC}=0.93 ; R^{2}=0.50\right.$ ), and is presented as an alternative (Table 4, Fig. 3).

Specific models to predict basal resprouting only and epicormic resprouting only (see Fig. 2) were also developed and performed

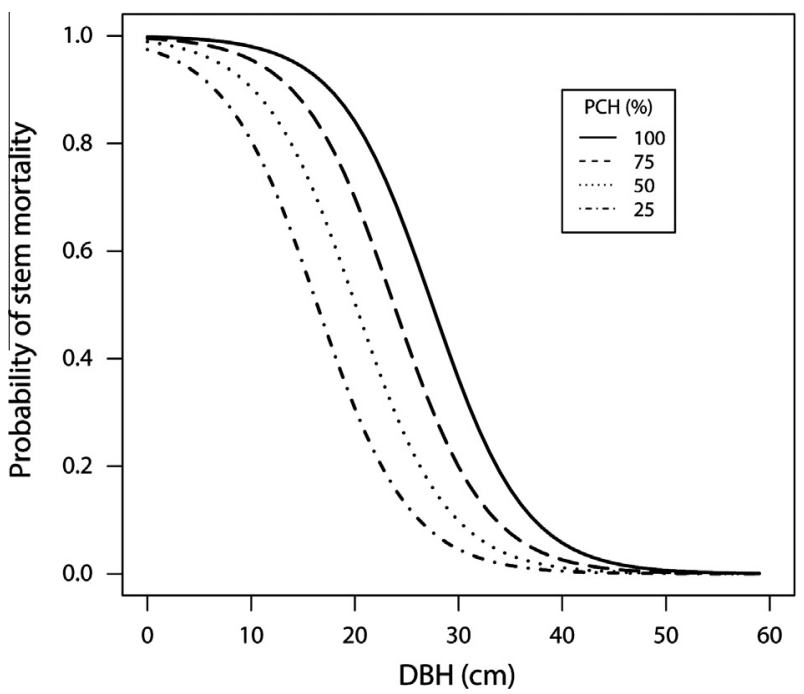

Fig. 3. Predicted probability of post-fire top-kill (stem mortality) for E. globulus trees as a function of diameter at $1.30 \mathrm{~m}(\mathrm{DBH})$ and fire severity (expressed by the proportion of maximum char height, $\mathrm{PCH}$ ). This alternative simpler model with only two variables still showed very good performance (see Table 4). well. Basal resprouting increased with $\mathrm{PCH}$ and decreased with DBH, while epicormic resprouting decreased with both $\mathrm{PCH}$ and CS (Table 5). There was a nearly significant $(P=0.061)$ positive effect of DBH in the epicormic resprouting model.

\subsection{Number and growth of basal resprouts}

Overall, $89.2 \%$ of eucalypt trees had post-fire basal regeneration, with varying number of resprouts (Fig. 4). Model results (Table 6) show that the number of basal resprouts per tree increased with char height $(\mathrm{PCH})$ and parent tree diameter $(\mathrm{DBH})$, was higher in top-killed individuals (TK), and decreased with slope (SL). Although we found these four variables to significantly influence the number of resprouts, the explained variance was not high $\left(R^{2}=0.11\right.$; Table 6$)$. Char height $(\mathrm{PCH})$ was the most important variable affecting the number of basal resprouts, while the remaining three variables accounted for little additional explained variance (about 2\%).

The growth of basal resprouts was remarkably fast and one year after fire the mean height of the dominant resprout ( $3.3 \mathrm{~m}$ ) was already nearly $25 \%$ of the mean pre-fire tree height $(13.6 \mathrm{~m}$; Table 2 , Fig. 5). The height of the dominant basal resprout (HDR) was positively related with the number of resprouts (NBR) and with char severity (CS); additionally HDR was lower in southern aspects (SA) (see Table 7).

\section{Discussion}

\subsection{Mortality and top-kill}

One year after fire, the large majority (96.1\%) of eucalypt trees were still alive, although most (79.2\%) were top-killed. We found that the probability of individual tree mortality significantly increased with fire severity (expressed by CS). None of the other variables assessed affected tree mortality. Although the ROC analysis indicated the usefulness of a model with only one predictor, the explained variance was quite low. The usually low fire-induced individual tree mortality observed in most temperate broadleaved species makes it difficult to establish relationships with potential explanatory variables, and several other studies found similar difficulties (Stephens and Finney, 2002; Franklin et al., 2006; Catry et al., 2010). In contrast, the developed models for predicting tree top-kill showed very good performance, and we could find significant relationships between top-kill and several explanatory variables. The most important predictors of E. globulus top-kill were the tree morphological traits, namely DBH and BT (which were not used simultaneously to avoid collinearity). These two variables were highly correlated $(r=0.99)$ as expected, and both decreased tree vulnerability to fire. In general, using BT instead of DBH resulted in slightly better model performance, suggesting that BT may be the main morphological trait conferring resistance to topkill; however, since differences were small and DBH is usually more easily available, we opted to present the models with this variable. Tree height $(\mathrm{H})$ was also highly correlated with $\mathrm{BT}(r=0.76)$ and DBH $(r=0.73)$, but showed considerably lower performance. Bark thickness has been shown to have an important influence on fire-induced responses of several broadleaved species worldwide, including eucalypt trees (Catry et al., 2010; Lawes et al., 2011; Brando et al., 2012). Bark can protect the tree vascular cambium and epicormic strands or buds from lethal temperatures during a fire, and small differences in BT have been reported to produce large differences in fire resistance and resilience to fire (Bond and Van Wilgen, 1996; Catry et al., 2012; Catry et al., 2013). Like BT, DBH has also been shown to increase fire resistance in several tree species (e.g.Woolley et al., 2012), including eucalypts (Catry et al., 
Table 5

Generalized linear mixed models to predict two types of E. globulus resprouting: (1) Basal resprouting only (above), and (2) epicormic resprouting only (below).

\begin{tabular}{|c|c|c|c|}
\hline Resprouting type & Coefficients & $\chi^{2}$ & $P$-value \\
\hline \multicolumn{4}{|l|}{ Basal only } \\
\hline$\beta_{0}$ & $2.017 \pm 0.544$ & - & - \\
\hline $\mathrm{DBH}$ & $-0.195 \pm 0.032$ & 55.886 & $<0.001$ \\
\hline $\mathrm{PCH}$ & $0.028 \pm 0.005$ & 34.576 & $<0.001$ \\
\hline \multicolumn{4}{|l|}{ Epicormic only } \\
\hline$\beta_{0}$ & $2.247 \pm 1.004$ & - & - \\
\hline $\mathrm{PCH}$ & $-0.086 \pm 0.038$ & 17.575 & $<0.001$ \\
\hline CS & $-1.828 \pm 0.609$ & 10.491 & 0.001 \\
\hline
\end{tabular}

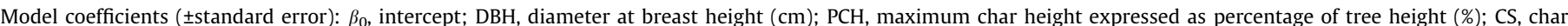

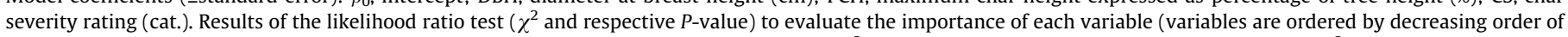
importance). Model fit: Basal resprouting model: Area under ROC curve $=0.89$; Nagelkerke $R^{2}=0.44$; Epicormic resprouting model: ROC $=0.96$; $R^{2}=0.50$.

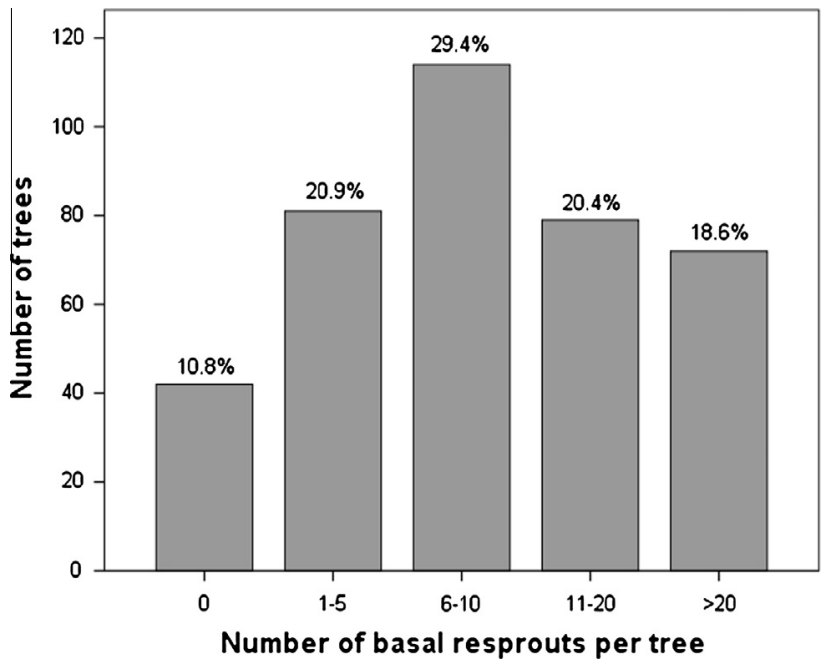

Fig. 4. Number (classes) of post-fire basal resprouts on 388 E. globulus trees.

Table 6

Generalized linear mixed model to predict the number of basal resprouts per tree (NBR) 1 year after fire.

\begin{tabular}{llll}
\hline & Coefficients & $\chi^{2}$ & $P$-value \\
\hline$\beta_{0}$ & $1.371 \pm 0.316$ & - & - \\
PCH & $0.013 \pm 0.002$ & 43.778 & $<0.001$ \\
SL & $-0.041 \pm 0.010$ & 15.862 & $<0.001$ \\
DBH & $0.031 \pm 0.011$ & 7.6028 & 0.006 \\
TK (yes) & $0.482 \pm 0.185$ & 6.9723 & 0.008 \\
\hline
\end{tabular}

Model coefficients ( \pm standard error): $\beta_{0}$, intercept; $\mathrm{PCH}$, maximum char height expressed as percentage of tree height (\%); SL, slope (\%); DBH, diameter at breast height $(\mathrm{cm})$; TK, top-killed tree (yes vs. no). Result of the likelihood ratio test $\left(\chi^{2}\right.$ and respective $P$-value) to evaluate the importance of each variable (variables are ordered by decreasing order of importance). Model fit: Nagelkerke $R^{2}=0.11$.

2010; Marques et al., 2011); however, it is not always obvious if this relationship is solely a result of the strong positive correlation between DBH and BT, or if it can be also a consequence of other factors, such as the lower probability of larger stems to be lethally damaged around the entire circumference (Gutsell and Johnson, 1996). Additionally, previous studies suggested that the epicormic structure of small-diameter eucalypt stems are in transition from axillary buds and meristems to fully developed epicormic strands (Burrows, 2000; Waters et al., 2010), which may be also a reason for lower epicormic resprouting potential of smaller trees. Other authors remarked that species like eucalypts or individuals within a species that tend to produce developed epicormic structures and retain persistent meristems may increase their epicormic potential over time as they grow (Meier et al., 2012). Our results

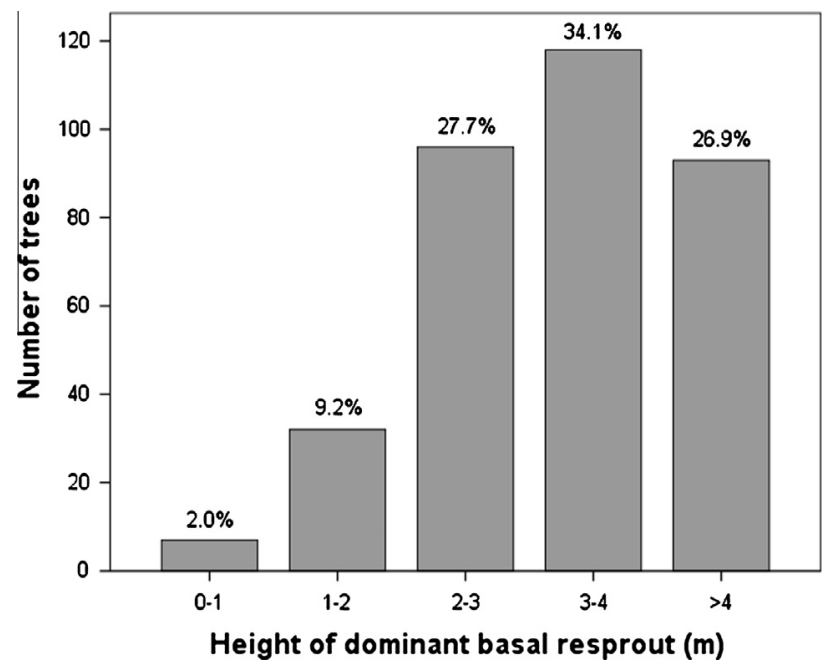

Fig. 5. Classes of height of the dominant basal resprout for 346 E. globulus trees with basal regeneration.

Table 7

Generalized linear mixed model to predict the height of the dominant basal resprout (HDR) 1 year after fire.

\begin{tabular}{llll}
\hline & Coefficients & $\chi^{2}$ & $P$-value \\
\hline$\beta_{0}$ & $2.010 \pm 0.403$ & - & - \\
NBR & $0.314 \pm 0.050$ & 37.328 & $<0.001$ \\
SA & $-0.271 \pm 0.118$ & 5.455 & 0.020 \\
CS & $0.341 \pm 0.143$ & 5.348 & 0.021 \\
\hline
\end{tabular}

Model coefficients ( \pm standard error): $\beta_{0}$, intercept; NBR, number of basal resprouts (categories); SA, location in southern aspects (yes vs. no); CS, char severity rating (categories). Result of the likelihood ratio test ( $\chi^{2}$ and respective $P$-value) to evaluate the importance of each variable (variables are ordered by decreasing order of importance). Model fit: Nagelkerke $R^{2}=0.11$.

clearly show that the probability of fire-induced tree top-kill sharply decreases with increasing DBH (or BT). Furthermore the presented model suggests that the probability of top-kill will be less than $50 \%$ when DBH exceeds $30 \mathrm{~cm}$, regardless of char height; however, since our sample included a small number of these large trees (because they are seldom found in eucalypt plantations; Table 2), these results should be confirmed in future studies.

In addition to morphological traits, the two fire severity indicators and four variables reflecting the stand structure and composition also influenced the probability of top-kill. Both the proportion of maximum char height (PHC) and bole char severity (CS) increased the likelihood of eucalypt top-kill, as expected. Char height correlates with flame height or fire intensity (e.g. Finney and Martin, 1993) and is one of the most widely used fire severity 
indicators, indirectly providing information on possible injury to cambial tissue or foliage (Regelbrugge and Conard, 1993; Thies et al., 2006; Woolley et al., 2012; Catry et al., 2013). On the other hand, char severity rating has also been used as an indicator of possible cambial damage from lethal heating, and may reflect differences in the fire residence time and energy released at the base of the tree (McHugh and Kolb, 2003; Woolley et al., 2012). The two fire severity indicators showed very low correlation $(r=0.19)$ and our results suggest that they are both useful and can be used complementarily to predict top-kill (and epicormic resprouting only).

Among the variables reflecting the forest stand structure and composition, total tree cover (TC), shrub cover (SC) and the proportion of pine trees (PP), all had a positive effect on eucalypt top-kill, while the proportion of other broadleaved tree species in the stand (PO) had a negative influence. The relationship between tree cover and top-kill may be explained by the higher crown bulk density of denser stands, which may sustain higher-intensity fires (Van Wagner, 1977) and therefore increase top-kill. Also crown fire spread is more likely in dense stands if the critical surface fire intensity for crowning is attained (Cruz et al., 2005; Castedo-Dorado et al., 2012). As regards to stand composition, maritime pine (P. pinaster) is a flammable species (Fernandes and Rigolot, 2007) and stands are known to be highly prone to fire (Nunes et al., 2005; Fernandes, 2009; Moreira et al., 2009b). In the case of mixed eucalypt and pine stands, fire hazard may be even higher, when compared with pure stands of eucalypts or pines (Moreira et al., 2009b). As to the presence of other broadleaves, the species found in the study plots (Quercus rotundifolia, Arbutus unedo, Q. faginea and Q. suber, by decreasing order of abundance) tend to have lower flammability than E. globulus, and thus could have contributed to decrease fire severity and hence, top-kill. Other studies in the Mediterranean Basin have shown that the presence of hardwoods (e.g. oaks) may contribute to decrease burn probability and fire severity (González et al., 2006; Fernandes et al., 2010).

Our results suggest that all the seven variables presented in the selected model (Table 4) are useful to predict tree top-kill, and each one gives an additional contribution to the explained variance. Although using seven predictors makes the model more complex, several of these variables can be obtained quite easily. Nevertheless, our results also suggest that it is possible to maintain a very good accuracy in the predictions using only $\mathrm{DBH}$ and $\mathrm{PCH}$ as predictors.

\subsection{Basal resprouting}

Most E. globulus trees (89.2\%) resprouted from basal buds and had live resprouts one year after the fire. Among these trees, nearly one third had 6-10 basal resprouts and $79.2 \%$ had less than 21 resprouts. The most important factor influencing the number of basal resprouts was $\mathrm{PCH}$; trees with higher levels of $\mathrm{PCH}$ tended to have more basal resprouts, thus indicating that increasing $\mathrm{PCH}$ did not cause a major reduction in the bud bank located belowground. Soil is a good insulator, and since heat input into the soil is a small fraction of the total heat released by fire, subterranean buds are usually well protected from lethal temperatures (Bond and Van Wilgen, 1996; Florence, 1996). Although there is relatively little information about the effect of fire severity on the number of basal resprouts, previous studies showed that different tree species may respond differently to increasing fire severity (Sampaio et al., 1993; Masaka et al., 2000). For example trees from the genus Betula, Caesalpinia and Quercus were reported to produce more resprouts when subjected to disturbances of increasing severity (Sampaio et al., 1993; Masaka et al., 2000; Bonfil et al., 2004). Moreover, the individuals with stem mortality and showing basal resprouting only, which had higher levels of PCH and were likely more severely damaged (e.g. Moreira et al., 2009a), tended to have more basal resprouts than those with simultaneous basal and epicormic resprouting. This may be explained by loss of apical dominance, which is mediated by hormones produced in actively growing stem tips and adjacent young leaves (Miller, 2000). Trees showing only basal resprouting are those in which all crown buds or bud producing structures were killed (either directly through heat or indirectly through the destruction of the vascular cambium in the stem); thus, the complete suppression of apical dominance in these individuals is expected to have a stronger effect in stimulating basal resprouting (Moreira et al., 2009a). On the other hand, trees showing epicormic resprouting were less affected by fire; in these cases, the presence of aboveground resprouts could cause weakened apical dominance (Kozlowski, 1971), preventing part of the bank of dormant basal buds from developing into new shoots (Miller, 2000).

Model results also showed that the number of basal resprouts decreased with slope and increased with parent tree DBH, although these factors explained little additional variability. Steeper slopes tend to retain less water, to be more susceptible to soil erosion and nutrient loss, and therefore soils in these slopes are usually thinner and less productive (e.g. Shakesby, 2011); these harsher conditions could reduce tree vigour and consequently their ability to produce and maintain viable resprouts. On the other hand the positive effect of DBH on the number of resprouts, may be explained by the presence of a larger bud bank and more belowground reserves in larger individuals (e.g. Bonfil et al., 2004; Quevedo et al., 2007), and by increased bud protection by bark thickness (e.g. Bond and Van Wilgen, 1996; Lawes et al., 2011). These results are in agreement with several studies of other tree species (e.g. Ross et al., 1986; Bonfil et al., 2004; Matula et al., 2012), although in other cases a negative relation was observed (e.g. Kauppi et al., 1988; Johansson, 2008). Indeed resprouting ability may vary with species and ontogenetic stage (Del Tredici, 2001; Vesk, 2006). Tree size is often positively related to age, but in coppice systems, like those of E. globulus, it is not possible to relate them without knowing the number of times each individual has been coppiced. Nevertheless, E. globulus is known to maintain its resprouting ability during several decades (e.g. Burns and Honkala, 1990), and Florence (1996) reported that in the case of eucalypts, where the tree is young enough to maintain its resprouting vigour, there may be a direct positive relationship between the number of resprouts and the diameter of the stump, which is consistent with our results.

The post-fire growth of the basal resprouts also ranged widely among trees, but in most cases $(61 \%)$ the dominant resprout was more than three meters high (Fig. 3). The fast growth of the resprouts is due to the high growth capacity of this eucalypt species and because they are linked to a large and well established root system (Skolmen and Ledig, 1990). The four studied wildfire sites burned in summer 2006, and tree assessment took place 12-14 months after fire, thus the resprouts grew under relatively similar conditions, particularly in terms of time since fire (76\% of all trees were assessed 12 months after fire). Three of the variables assessed (NBR, SA and CS) had a significant influence on the height of the dominant resprout (Table 7 ). The more important one was the number of basal resprouts, which had a positive effect on the height of the tallest resprout. This might be directly related to competition between basal resprouts for light, which lead the dominant one to grow taller, or the number of resprouts could be an indirect indicator of the carbohydrate reserves available in parent trees, since such reserves have been shown to positively affect both the number and growth of resprouts (Walters et al., 2005). Although contradictory reports exist in the literature, other authors found a significant positive relationship between the number of resprouts and the height of the dominant resprout 
in several broadleaved species (Masaka et al., 2004; Imanishi et al., 2010).

We also found that the height of the dominant basal resprout was lower in trees growing in southern aspects. In the Mediterranean Basin, south-facing slopes receive higher solar radiation, which increase temperature and reduce water availability to plants (Kutiel and Lavee, 1999; Sternberg and Shoshany, 2001). These unfavourable drier conditions are likely the reason for the smaller growth of resprouts in southern aspects (Konstantinidis et al., 2006). Results also suggest that the height of the dominant resprout increased with CS; a possible explanation to this could be that basal resprouts may have benefited from the lower competition for resources at the tree and/or at the site level, due to lower levels of epicormic resprouting and higher levels of understory elimination (Clarke et al., 2013; Quevedo et al., 2013).

Although we found several variables to significantly affect both the number of basal resprouts and the height of the dominant resprout, the variability explained by the models was not high (Tables 6 and 7). Basal regeneration of E. globulus could be more affected by other factors such as individual tree carbohydrate reserve pools and genotypic variation (Walters et al., 2005), and also by differences in the environmental conditions of the microsite and site quality (Malanson and Trabaud, 1988; Espelta et al., 2003; Gracia and Retana, 2004). For example concerning tree reserves, Walters et al. (2005) found that E. obliqua plants with larger carbohydrate reserve pools prior to disturbance (associated with larger lignotubers), supported production of a greater number of resprouts of greater total biomass than plants with smaller reserves. In our study the size of the parent tree at the time of the fire (indicated by $\mathrm{DBH}$ or $\mathrm{H}$ ) was weakly but positively related with the number of basal resprouts, but it did not influence the height of the dominant resprout. In undisturbed forests, larger individuals are often more vigorous and are expected to have larger pools of carbohydrate reserves, thus it could be also expected that their resprouts would grow taller; however, in a coppice system where trees are regularly felled, in most cases tree size per se cannot be directly related to tree age or vigour. Thus, knowing the age of the trees (for example by knowing the number of previous coppicing rotations), could potentially be useful information for predicting post-fire resprouting intensity and growth. Other variables such as the disturbance history of individual plants (e.g. previous fires or extreme drought; López et al., 2009), the number of pre-fire stems in each stump (Johnson, 1975; Ducrey and Turrel, 1992), the source provenance of the planted trees (Walters et al., 2005) or site characteristics, such as soil depth (López-Soria and Castell, 1992), could possibly improve our ability to predict tree responses to fire.

\subsection{Management implications}

Understanding how trees respond to fire and which are the factors driving such responses is important for assisting pre- and post-fire management decisions, particularly in ecosystems where fire is a recurrent disturbance. The presented models may be useful to help managers in the assessment of post-fire production losses and regeneration potential in E. globulus plantations. They may also be useful to help estimating the fire effects on carbon stocks, on soil erosion, or as guidance to prescribed burning operations.

In general, all management actions contributing to decrease fire intensity and severity in E. globulus stands (e.g. reflected by a reduction of char height or char depth) will likely increase the probability of tree and stem survival. Our results specifically suggest that reducing vegetation cover, reducing the proportion of pine trees and increasing the proportion of other (less flammable) broadleaved trees may contribute to decrease the probability of top-kill. Results also suggest that post-fire basal resprouting tend to be less vigorous under harsher topographic conditions (namely steeper terrains and southern aspects), thus managers may want to consider avoiding them (e.g. when planning new plantations), in order to increase resilience to fire.

\section{Acknowledgements}

The present study was funded by the Portuguese government, FFP (project Recuperação de Áreas Ardidas) and FCT (PhD grant SFRH/BD/65991/2009; project PTDC/ AGRCFL/099420/2008). Special thanks to Rui Morgado for his help during field work. We also thank two anonymous reviewers for their useful suggestions to improve the paper.

\section{References}

Amatulli, G., Camia, A., San-Miguel-Ayanz, J., 2013. Estimating future burned areas under changing climate in the EU-Mediterranean countries. Science of the Total Environment 450-451, 209-222.

Bates, D., Maechler, M., Bolker, B., 2009. Ime4: Linear mixed-effects models using S4 classes. $\mathrm{R}$ package version 0.999375-32. <http://CRAN.R-project.org/ package $=$ lme4>. (accessed January 2013).

Bond, W.J., Van Wilgen, B.W., 1996. Fire and plants, Chapman and Hall, London.

Bonfil, C., Cortés, P., Espelta, J.M., Retana, J., 2004. The role of disturbance in the coexistence of the evergreen Quercus ilex and the deciduous Quercus cerrioides. Journal of Vegetation Science 15, 423-430.

Brando, P.M., Nepstad, D.C., Balch, J.K., Bolker, B., Christman, M.C., Coe, M., Putz, F.E., 2012. Fire-induced tree mortality in a neotropical forest: the roles of bark traits, tree size, wood density and fire behavior. Global Change Biology 18, 630-641.

Burns, R.M., Honkala, B.H.T.c., 1990. Silvics of North America: Hardwoods. United States Department of Agriculture (USDA), Forest Service, vol. 2. Washington, DC. Burrows, G.E., 2000. An anatomical study of epicormic bud strand structure in Eucalyptus cladocalyx (Myrtaceae). Australian Journal of Botany 48, 233-245.

Burrows, G.E., 2002. Epicormic strand structure in Angophora, Eucalyptus and Lophostemon (Myrtaceae) - implications for fire resistance and recovery. New Phytologist 153, 111-131.

Burrows, G.E., 2013. Buds, bushfires and resprouting in the eucalypts. Australian Journal of Botany 61, 331-349.

Castedo-Dorado, F., Gómez-Vázquez, I., Fernandes, P.M., Crecente-Campo, F., 2012. Shrub fuel characteristics estimated from overstory variables in NW Spain pine stands. Forest Ecology and Management 275, 130-141.

Catry, F., Moreira, F., Duarte, I., Acácio, V., 2009. Factors affecting post-fire crown regeneration in cork oak trees in Southern Portugal. European Journal of Forest Research 128, 231-240.

Catry, F.X., Rego, F., Moreira, F., Fernandes, P.M., Pausas, J.G., 2010. Post-fire tree mortality in mixed forests of central Portugal. Forest Ecology and Management 260, 1184-1192.

Catry, F.X., Moreira, F., Pausas, J.G., Fernandes, P.M., Rego, F., Cardillo, E., Curt, T., 2012. Cork oak vulnerability to fire: the role of bark harvesting, tree characteristics and abiotic factors. PLoS ONE 7, e39810.

Catry, F.X., Pausas, J.G., Moreira, F., Fernandes, P.M., Rego, F., 2013. Post-fire response variability in Mediterranean Basin tree species in Portugal. International Journal of Wildland Fire, <http://dx.doi.org/10.1071/WF12215>.

Clarke, P.J., Lawes, M.J., Midgley, J.J., Lamont, B.B., Ojeda, F., Burrows, G.E., Enright, N.J., Knox, K.J.E., 2013. Resprouting as a key functional trait: how buds, protection and resources drive persistence after fire. New Phytologist 197, 1935.

Cruz, M.G., Alexander, M.E., Wakimoto, R.H., 2005. Development and testing of models for predicting crown fire rate of spread in conifer forest stands. Canadian Journal of Forest Research 35, 1626-1639.

DeBano, L.F., Neary, D.G., Ffolliott, P.F., 1998. Fire's effects on ecosystems. John Wiley \& Sons, Inc., New York.

Del Tredici, P., 2001. Sprouting in temperate trees: a morphological and ecological review. The Botanical Review 67, 121-140.

Ducrey, M., Turrel, M., 1992. Influence of cutting methods and dates on stump sprouting in Holm oak (Quercus ilex L) coppice. Annals of Forest Science 49, 449-464.

Dutkowski, G.W., Potts, B.M., 1999. Geographic patterns of genetic variation in Eucalyptus globulus ssp. globulus and a revised racial classification. Australian Journal of Botany 47, 237-263.

Espelta, J.M., Retana, J., Habrouk, A., 2003. Resprouting patterns after fire and response to stool cleaning of two coexisting Mediterranean oaks with contrasting leaf habits on two different sites. Forest Ecology and Management $179,401-414$.

Fernandes, P.M., 2009. Combining forest structure data and fuel modelling to classify fire hazard in Portugal. Annals of Forest Science 66, 415.

Fernandes, P., Rigolot, E., 2007. The fire ecology and management of maritime pine (Pinus pinaster Ait.). Forest Ecology and Management 241, 1-13.

Fernandes, P.M., Luz, A., Loureiro, C., 2010. Changes in wildfire severity from maritime pine woodland to contiguous forest types in the mountains of northwestern Portugal. Forest Ecology and Management 260, 883-892. 
Fernandes, P.M., Loureiro, C., Palheiro, P., Vale-Gonçalves, H., Fernandes, M.M., Cruz, M.G., 2011. Fuels and fire hazard in blue gum (Eucalyptus globulus) stands in Portugal.

Finney, M.A., Martin, R.E., 1993. Modeling effects of prescribed fire on younggrowth coast redwood trees. Canadian Journal of Forest Research 23, 11251135.

Flannigan, M., Krawchuk, M., Groot, W., Wotton, B., Gowman, L., 2009. Implications of changing climate for global wildland fire. International Journal of Wildland Fire 18, 483-507.

Florence, R.G., 1996. Ecology and Silviculture of Eucalypt Forests CSIRO Publishing, Collilgwood, Victoria.

Franklin, J., Spears-Lebrun, L.A., Deutschman, D.H., Marsden, K., 2006. Impact of a high-intensity fire on mixed evergreen and mixed conifer forests in the Peninsular Ranges of southern California, USA. Forest Ecology and Management $235,18-29$.

Gill, A.M., 1997. Eucalypts and fires: interdependent or independent? In: Williams, J., Woinarski, J. (Eds.), Eucalypt ecology: individuals to ecosystems. Cambridge Univ Press, Cambridge, pp. 151-167.

Goes, E., 1977. Os eucaliptos - ecologia, culturaprodução e rentabilidade. Portucel, Lisboa.

González, J.R., Palahí, M., Trasobares, A., Pukkala, T., 2006. A fire probability model for forest stands in Catalonia (north-east Spain). Annals of Forest Science 63, 169-176.

Gracia, M., Retana, J., 2004. Effect of site quality and shading on sprouting patterns of holm oak coppices. Forest Ecology and Management 188, 39-49.

Gutsell, S.L., Johnson, E.A., 1996. How fire scars are formed: coupling a disturbance process to its ecological effect. Canadian Journal of Forest Research 26, 166-174.

Hosmer, D.W., Lemeshow, S. 2000. Applied logistic regression. Wiley, New York. John Wiley \& Sons, New York.

ICNF, 2013. IFN6 - Áreas dos usos do solo e dasespéciesflorestaisde Portugal continental. Resultadospreliminares. In. Instituto da Conservação da Natureza e dasFlorestas, Lisboa, p. 33.

Imanishi, A., Morimoto, J., Imanishi, J., Shibata, S., Nakanishi, A., Osawa, N., Sakai, S. 2010. Sprout initiation and growth for 3 years after cutting in an abandoned secondary forest in Kyoto, Japan. Landscape and Ecological Engineering 6, 325333.

Johansson, T., 2008. Sprouting ability and biomass production of downy and silver birch stumps of different diameters. Biomass \& Bioenergy 32, 944-951.

Johnson, P.S., 1975. Growth and structural development of red oak sprout clumps. Forest Science 21, 413-418.

JRC, 2012. Forest fires in Europe Middle East and North Africa 2011. In: Reports, J.S.a.T. (Ed.), Joint Research Centre Ispra, p. 108.

Kauppi, A., Rinne, P., Ferm, A., 1988. Sprouting ability and significance for coppicing of dormant buds on Betula pubescensEhrh. stumps. Scandinavian Journal of Forest Research 3, 343-354.

Konstantinidis, P., Tsiourlis, G., Xofis, P., 2006. Effect of fire season, aspect and prefire plant size on the growth of Arbutus unedo L. (strawberry tree) resprouts. Forest Ecology and Management 225, 359-367.

Kozlowski, T.T., 1971. Growth and development of trees, vol. 1. Academic Press, New York.

Kutiel, P., Lavee, H., 1999. Effect of slope aspect on soil and vegetation properties along an aridity transect. Israel Journal of Plant Sciences 47, 169-178.

Lawes, M.J., Adie, H., Russell-Smith, J., Murphy, B., Midgley, J.J., 2011. How do small savanna trees avoid stem mortality by fire? The roles of stem diameter, height and bark thickness. Ecosphere 2, art42.

López, B.C., Gracia, C.A., Sabaté, S., Keenan, T., 2009. Assessing the resilience of Mediterranean holm oaks to disturbances using selective thinning. ActaOecologica 35, 849-854.

López-Soria, L., Castell, C., 1992. Comparative genet survival after fire in woody Mediterranean species. Oecologia 91, 493-499.

Malanson, G.P., Trabaud, L., 1988. Vigor of post-fire resprouting by Quercus coccifera L. Journal of Ecology 76, 351-365.

Manel, S., Williams, H.C., Ormerod, S.J., 2001. Evaluating presence-absence models in ecology: the need to account for prevalence. Journal of Applied Ecology 38, 921-931.

Marques, S., Garcia-Gonzalo, J., Borges, J.G., Botequim, B., Oliveira, M.M., Tome, J., Tome, M., 2011. Developing post-fire Eucalyptus globulus stand damage and tree mortality models for enhanced forest planning in Portugal. Silva Fennica 45, 69-83.

Masaka, K., Ohno, Y., Yamada, K., 2000. Fire tolerance and the fire-related sprouting characteristics of two cool-temperate broad-leaved tree species. Annals of Botany 85, 137-142.

Masaka, K., Ohno, Y., Yamada, K., 2004. Recovery of canopy trees and root collar sprout growth in response to changes in the condition of the parent tree after a fire in a cool-temperate forest. Journal of Forest Research 9, 271-275.

Matula, R., Svatek, M., Kurova, J., Uradnicek, L., Kadavy, J., Kneifl, M., 2012. The sprouting ability of the main tree species in Central European coppices: implications for coppice restoration. European Journal of Forest Research 131, 1501-1511.

McHugh, C.W., Kolb, T.E., 2003. Ponderosa pine mortality following fire in northern Arizona. International Journal of Wildland Fire 12, 7-22.

Meier, A.R., Saunders, M.R., Michler, C.H., 2012. Epicormic buds in trees: a review of bud establishment, development and dormancy release. Tree Physiology 32, $565-584$.

Miller, M., 2000. Fire autecology. In: Brown, J.K., Smith, J.K. (Eds.), Wildland Fire in Ecosystems - Effects of Fire on Flora. U.S. Department of Agriculture, Forest Service, Rocky Mountain Research Station, Ogden, UT, pp. 9-34.
Moreira, F., Duarte, I., Catry, F., Acácio, V., 2007. Cork extraction as a key factor determining post-fire cork oak survival in a mountain region of southern Portugal. Forest Ecology and Management 253, 30-37.

Moreira, F., Catry, F., Duarte, I., Acácio, V., Silva, J.S., 2009a. A conceptual model of sprouting responses in relation to fire damage: an example with cork oak (Quercus suber L.) trees in Southern Portugal. Plant Ecology 201, 77-85.

Moreira, F., Vaz, P., Catry, F., Silva, J.S., 2009b. Regional variations in wildfire preference for land cover types in Portugal: implications for landscape management to minimize fire hazard. International Journal of Wildland Fire $18,563-574$.

Nagelkerke, N.J.D., 1991. A note on a general definition of the coefficient of determination. Biometrika 78, 691-692.

Nicolle, D., 2006. A classification and census of regenerative strategies in the eucalypts (Angophora, Corymbia and Eucalyptus-Myrtaceae), with special reference to the obligate seeders. Australian Journal of Botany 54, 391-407.

Nunes, M.C.S., Vasconcelos, M.J., Pereira, J.M.C., Dasgupta, N., Alldredge, R.J., Rego, F.C., 2005. Land cover type and fire in Portugal: do fires burn land cover selectively? Landscape Ecology 20, 661-673.

Pearce, J., Ferrier, S., 2000. Evaluating the predictive performance of habitat models developed using logistic regression. Ecological Modelling 133, 225-245.

Pohjonen, V., Pukkala, T., 1990. Eucalyptus globulus in Ethiopian forestry. Forest Ecology and Management 36, 19-31.

Potts, B.M., 2004. Genetic improvement of eucalypts. In: Encyclopedia of Forest Sciences. Elsevier, Oxford, UK, pp. 1480-1490.

Potts, B.M., Vaillancourt, R.E., Jordan, G.J., Dutkowski, G.W., Costa e Silva, J., McKinnon, G.E., Steane, D.A., Volker, P.W., Lopez, G.A., Apiolaza, L.A., Li, Y. Marques, C., Borralho, N.M.G., 2004. Exploration of the Eucalyptus globulus gene pool. In: Borralho, N.M.G., Pereira, J.S., Marques, C., Coutinho, J., Madeira, M. Tomé, M. (Eds.), Eucalyptus in a changing world. RAIZ, InstitutoInvestigação deFloresta e Papel, Aveiro, Portugal, pp. 46-61.

Quevedo, L., Rodrigo, A., Espelta, J.M., 2007. Post-fire resprouting ability of 15 nondominant shrub and tree species in Mediterranean areas of NE Spain. Annals of Forest Science 64, 883-890.

Quevedo, L., Arnan, X., Rodrigo, A., 2013. Selective thinning of Arbutus unedo coppices following fire: effects on growth at the individual and plot level. Forest Ecology and Management 292, 56-63.

R Development Core Team, 2010. R: a language and environment for statistical computing. R Foundation for Statistical Computing, Vienna, Austria. <http:// www.R-project.org>. (accessed January 2013).

Regelbrugge, J.C., Conard, S.G., 1993. Modeling tree mortality following wildfire in Pinus ponderosa forests in the central Sierra-Nevada of California. International Journal of Wildland Fire 3, 139-148.

Rothermel, R.C., 1983. How to predict the spread and intensity of forest and range fires. In: Service, U.F. (Ed.), General Technical Report. Intermountain Forest and Range Experiment Station, Ogden, p. 164.

Ross, M.S., Sharik, T.L., Smith, D.W., 1986. Oak regeneration after clear felling in southwest Virginia. Forest Science 32, 157-169.

Ryan, K.C., 1982. Evaluating potential tree mortality from prescribed burning. In: Baumgartner, D.M. (Ed.), Site preparation and fuels management on steep terrain. Washington State University, Cooperative Extension, Pullman, WA, pp. $167-179$.

Sampaio, E.V.S.B., Salcedo, I.H., Kauffman, J.B., 1993. Effect of different fire severities on coppicing of caatinga vegetation in SerraTalhada, PE, Brazil. Biotropica 25 452-460.

Shakesby, R.A., 2011. Post-wildfire soil erosion in the Mediterranean: review and future research directions. Earth Science Reviews 105, 71-100.

Silva, J.S., Moreira, F., Vaz, P., Catry, F., Godinho-Ferreira, P., 2009. Assessing the relative fire proneness of different fores types in Portugal. Plant Biosystems 143 597-608.

Skolmen, R.G., Ledig, T., 1990. Eucalyptus globulusLabill. Bluegum eucalyptus. In: Burns, R.M., Honkala, B.H. (Eds.), Silvics of North America: Hardwoods. United States Department of Agriculture (USDA), Forest Service, Agriculture Handbook 654 , vol. 2, Washington, DC.

Stephens, S.L., Finney, M.A., 2002. Prescribed fire mortality of Sierra Nevada mixed conifer tree species: effects of crown damage and forest floor combustion. Forest Ecology and Management 162, 261-271.

Sternberg, M., Shoshany, M., 2001. Influence of slope aspect on Mediterranean woody formations: comparison of a semiarid and an arid site in Israel Ecological Research 16, 335-345.

Strasser, M.J., Pausas, J.G., Noble, I.R., 1996. Modelling the response of eucalypts to fire, Brindabella Ranges, ACT. Australian Journal of Ecology 21, 341-344.

Swets, J.A., 1988. Measuring the accuracy of diagnostic systems. Science 240, 1285 1293.

Thies, W.G., Westlind, D.J., Loewen, M., Brenner, G., 2006. Prediction of delayed mortality of fire-damaged ponderosa pine following prescribed fires in eastern Oregon, USA. International Journal of Wildland Fire 15, 19-29.

Thies, W.G., Westlind, D.J., 2012. Validating the Malheur model for predicting ponderosa pine post-fire mortality using 24 fires in the Pacific Northwest, USA. International Journal of Wildland Fire 21, 572-582.

Van Wagner, C.E., 1977. Conditions for the start and spread of crown fire. Canadian Journal of Forest Research 7.

Vesk, P.A., 2006. Plant size and resprouting ability: trading tolerance and avoidance of damage? Journal of Ecology 94, 1027-1034.

Vivian, L.M., Cary, G.J., Bradstock, R.A., Gill, A.M., 2008. Influence of fire severity on the regeneration, recruitment and distribution of eucalypts in the Cotter Rive Catchment, Australian Capital Territory. Austral Ecology 33, 55-67. 
Walters, J.R., Bell, T.L., Read, S., 2005. Intra-specific variation in carbohydrate reserves and sprouting ability in Eucalyptus obliqua seedlings. Australian Journal of Botany 53, 195-203.

Waters, D.A., Burrows, G.E., Harper, J.D.I., 2010. Eucalyptus regnans (Myrtaceae): a fire-sensitive eucalypt with a resprouterepicormic structure. American Journa of Botany 97, 545-556.

Whelan, R.J., 1995. The Ecology of Fire. Cambridge University Press, New York

Whittock, S.P., Apiolaza, L.A., Kelly, C.M., Potts, B.M., 2003. Genetic control of coppice and lignotuber development in Eucalyptus globulus. Australian Journal of Botany 51, 57-68.
Woolley, T., Shaw, D.C., Ganio, L.M., Fitzgerald, S., 2012. A review of logistic regression models used to predict post-fire tree mortality of western North American conifers. International Journal of Wildland Fire 21, 1-35.

Xanthopoulos, G., Calfapietra, C., Fernandes, P., 2012. Fire hazard and flammability of European forest types. In: Moreira, F., Arianoutsou, M., Corona, P., de las Heras, J., (Eds.), Post-fire management and restoration of European forests. Managing Forest Ecosystems, Springer, vol. 24, pp. 79-92.

Zuur, A.F., Ieno, E.N., Walker, N.J., Saveliev, A.A., Smith, G.M., 2009. Mixed effects models and extensions in ecology with R. Springer, New York. 